\title{
Assessment of diameters of karst holes in the design of the main gas pipeline, South Yakutia
}

\author{
Ludmila Strokova ${ }^{1, *}$, and Aloyna Ezhkova $^{1}$ \\ ${ }^{1}$ Tomsk Polytechnic University, Geology Division, 634050 Tomsk, av. Lenina, 30, Russia
}

\begin{abstract}
The report describes the local and regional geological factors of the South Yakutia, through which it is planned to build a gas pipeline. On this territory there are the main karstic rocks, with relatively high=mineral solubilities: dolomite, limestone and gypsum. These rocks have different dissolution rates and others geological settings. The assessment of the karst holes diameters for the gas pipeline section was made. The measures to protect potentially hazardous sections are suggested, including timely notification about sinkholes.
\end{abstract}

\section{Introduction}

\subsection{Significance of the problem}

The design and construction of engineering structures in karst regions confronts many problems due to unpredictable location, dimensions and geometry of the karst structure and voids. Subsurface voids in karst are unpredictable. Every site in such terrain has to be assessed individually in the context of its geology and geomorphology. Constructing gas pipelines in the areas characterized by unfavourable environmental conditions, such as boggy areas or zones of ever-frozen subsoil, is a current challenge for Russia and preliminary investigations of these territories are needed. The issue is particularly important when the pipelines are constructed in the territories with frozen karst, for instance, the Lena tableland in the South Yakutia. To prevent gas pipeline failures, it is necessary to develop the measures which ensure timely informing on sinkhole collapses.

The karst phenomenon has been researched in the works of many Russian and foreign scientists. This is due to the fact that karst zones are varied and widely spread. In the works by N.A. Gvozdetsky [1-2], G.A. Maksimovich [3] the following questions were discussed: solubility of karst rocks under different physiographic and geological conditions, the mechanism of karst collapse, stability assessment in karst areas, the efficient methods to detect karst cavities in the course of land development.

The objective of this paper is to assess karst hazards for the first section of the main gas pipeline "The Power of Siberia» using different geological methods: geoengineering, geophysical, hydrogeological, and mapping. On the data basis have been identified the

*Corresponding author: sla@tpu.ru 
areas prone to karst development and the appropriate measures to protect potentially hazardous sections are suggested, including timely notification about sinkholes.

\subsection{Study area}

The study area is located in Lensk Ulus, the Republic of Sakha (Yakutia). The description of geoengineering conditions is provided on the report, which contains the data by VostSibAGE, Promneftegazproyekt, Ingeokom, Fundamentproyekt, SPF DIEM, IPE RAS obtained in the exploration work for pipeline route in 2010-2012. The length of the track was $160 \mathrm{~km}$. The region is poorly studied and the lands are poorly reclaimed.

The climate of the region is sharp continental, with lukewarm summer and severe dry and cold winter. The average annual air temperature ranges from $-5.6{ }^{\circ} \mathrm{C}$ to $-6.2{ }^{\circ} \mathrm{C}$. The annual amount of precipitation is about $346-409 \mathrm{~mm}, 75 \%$ of which fall during the warm period.

In terms of geomorphology, the gas pipeline route stretches through the Prilensk erosive tectonics plateau bound by the Patom highland in the southeast and by the Leno-Vilyuysk basin in the north and northeast. The surface of the plateau is 400-600 m above sea level and is tilted gently to the northwest. The highest point above the sea level is Byugyuekh watershed divide $(554 \mathrm{~m})$ and the lowest point is the valley of the Nuia river $(243 \mathrm{~m})$. The erosion and denudation landforms are predominant [4].

In terms of tectonics, the region is located in the southern part of the Siberian platform, beginning from the Nepsky arch of the Nepsko-Botuobinsk anticline and moving to Predpatomsk depression. The area is composed of Cambrian and Ordovician sediments as comb-shaped folds extending to the north-east along the border of Baykal-Patom mantle folded formation. The folds are fractured predominantly with south-east thrusting. There are also transverse steeply dipping submeridional strike fractures. Two sections of the track cross the zones of Jurassic sediments overlying Lower Paleozoic sediments with angular unconformity. The summary information on the region geology is represented in Table 1.

Table 1. The geology of the studied region.

\begin{tabular}{|c|l|l|}
\hline № & \multicolumn{1}{|c|}{$\begin{array}{c}\text { Sediment age } \\
\text { period }- \text { thickness, } \mathbf{m}\end{array}$} & \multicolumn{1}{c|}{ Lithologic composition of sediments } \\
\hline 1 & $\begin{array}{l}\text { Cenozoic } \\
\text { Quartenary }-<10\end{array}$ & $\begin{array}{l}\text { Low ice-content clay loam, sand clay, } \\
\text { pebble, gruss, peat }\end{array}$ \\
\hline 2 & $\begin{array}{l}\text { Mezozoic } \\
\text { Jurassic }-90\end{array}$ & $\begin{array}{l}\text { Diversely-grained sand with sandstone and } \\
\text { conglomerate lamina }\end{array}$ \\
\hline 3 & $\begin{array}{l}\text { Paleozoic } \\
\text { Ordovician }-300 \\
\text { Cambrian }-1300\end{array}$ & $\begin{array}{l}\text { Aleurolite, argillite, } \\
\text { Limestone, dolomite }\end{array}$ \\
\hline
\end{tabular}

On the seismic zoning map the track crosses the zone with seismic intensity of 6 points of MSK-64 scale.

Within the region genetic stratigraphic sequence of primary rocks and quarternary deposits are selected. Primary rocks are provided by two formations: carbonate Lower Cambrian and terrigenous-carbonate Middle Cambrian and Ordovician. Among quarternary deposits the following genetic types are selected: alluvial, alluvial-diluvial, diluvialproluvial, diluvial-colluvial, colluvial, eluvial, eluvial-deluvial, biogenic.

The region is within the area of discontinuous permafrost. The discontinuous permafrost and scarce icy ground of the region determine the character of cryogenic processes: oneyear cryogenic formations, which break on-season, are predominant - flood icing and one- 
year frost mounds, which emerge from time to time and change the place of emergence $[5,6]$.

Karsts are widely spread in carbonate formations. Intensive karst development takes place due to fissured lands and fractured rocks. Karst development is caused by dissolution of carbonate rocks by surface and ground waters. The process is intense in fractured zones of smooth carbonate in the anticlinal core. Cambrian carbonates include calcium sulphate, and limestone, and as a result, both the thickness and the extension of karst zones vary significantly.

The underground waters are characterized by sporadic distribution. The waters within thin diluvial formations at slopes are found at the depth of 3-5 m. A majority of water composition from boreholes and streams belongs to $\mathrm{Ca}-\mathrm{HCO}_{3}$ type (Fig.1).

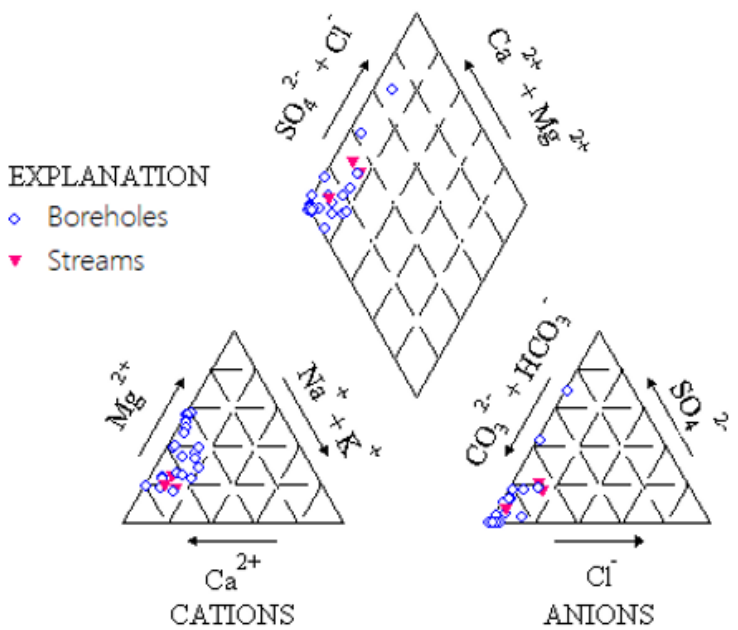

Fig. 1. Piper plot showing the chemical compositions and types of water for boreholes and streams.

In the course of exploration different forms of karst were identified - karst windows and sinking streams. The diameters of the karst window vary from 10 to $50 \mathrm{~m}$ and the depth ranges from 0.5 to $3.3 \mathrm{~m}$. The process of karst development within some windows is quite intense which is indicated by recently fallen trees. The sinks have $5 \mathrm{~m}$ in width and $3 \mathrm{~m}$ in depth. The $10 \mathrm{~m}$ well drilled within the karst window revealed uncovered loam soils and sandy medium gravel clay. The hard limestone at the window periphery at the depth of 1.5-3.0 m, was not found. Ground water was not observed as well.

Sinking streams can be observed in slightly sloping depression which stretches along the slope for $1 \mathrm{~km}$. The well drilled at the edge of the depression uncovered homogeneous formation of medium gravel loam soils while rocks and ground water were not identified.

The karst channel was identified on the left bank of the Tokunda river. At the interval between $10-13 \mathrm{~m}$ and $3 \mathrm{~m}$ below surface was found the layer of medium hard limestone belonging to decompressed zone. It was filled with sandy clay with noncoherent limestone clasts. Ground water was not found. The zones of potential karst hazard are smooth carbonate formations of watershed divides, gentle slopes, and valley bottoms. Slope and erosion exogenous process, as well as bogging and suffusion, are less intense within the study area.

In order to provide the necessary information for designing pipeline it is necessary to study karst distribution. 


\section{Methods \& Results}

One of the key issues in karst research is karst related zoning. The average annual intensity of karst sinkhole development (number of sinkholes $/ \mathrm{km}^{2}$ per year) was suggested by Z.A. Makeev [7] in 1948 and has been the conventional measure to assess karst hazard for a long time. We support the idea of V.V. Tolmachev et al. [8] that the appropriate basic criterion to assess karst hazard is the diameter of the sinkholes.

Since the data on intensity of karst sinkhole development, including measurements of diameters and sinkholes ages are not enough in the study area, we suggested assessment based on the integral criterion of potential karst development.

To provide rationale for the karst hazard criteria, we analysed the data collected from various karst areas. The data allowed recognizing the evidences of karst hazard lithological composition of rocks, hydrogeological characteristics and fracturing.

The mechanism of formation of karst holes is the basis of the design schemes for determining the diameter of the karst hole.

This mechanism is closely related to the geological structure of the area, physical and mechanical properties of rocks, and hydrogeological conditions that change with time.

On the gas pipeline route during the complex engineering surveys, five decompressed zones were recorded. These areas are the most promising as areas for the formation of karst holes.

To assess the karst hazard of the area, we calculated the diameters of karst holes $\mathrm{d}_{0}$ using the equations [8]. The diameter of the sinkhole $\mathrm{d}_{0}$ is determined by the equilibrium condition of the cylindrical column of soil hovering over the karst cavity. The forces of cohesion and friction ( $\Sigma \mathrm{T})$ acting on its lateral surface balance the weight of the soil column with the thickness $\mathrm{z}$. The shear forces $(\Sigma \mathrm{F})$ seeking to move the soil column downwards are summed from the ground cylinder's own weight and the external load (fig.2).

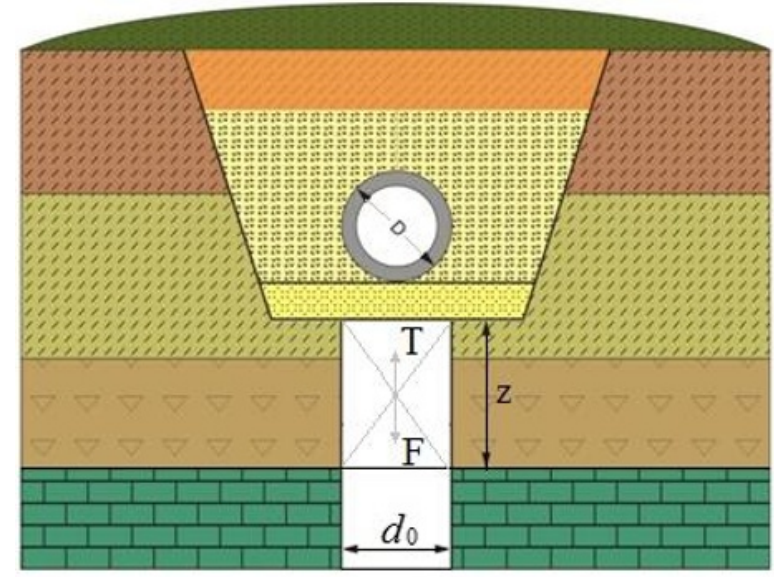

Fig. 2. Scheme for determining the diameter of the karst hole under the pipeline with a diameter D.

As the result of our study, the pipeline route is split into sections, which are considered hazardous, potentially hazardous, and nonhazardous in relation to karst development (fig.3). Hazardous zones are those with karst landforms, with no aquiclude on top of soluble rocks or with the thickness less than $5 \mathrm{~m}$. The calculated diameter of the karst hole varies from 0.1 to $2.1 \mathrm{~m}$ here. Potentially hazardous zones are those composed of loosened rocks, with the aquiclude overlying soluble rocks or with the thickness from 5 to $10 \mathrm{~m}$. Nonhazardous zones are those with the aquiclude overlying soluble rocks. 


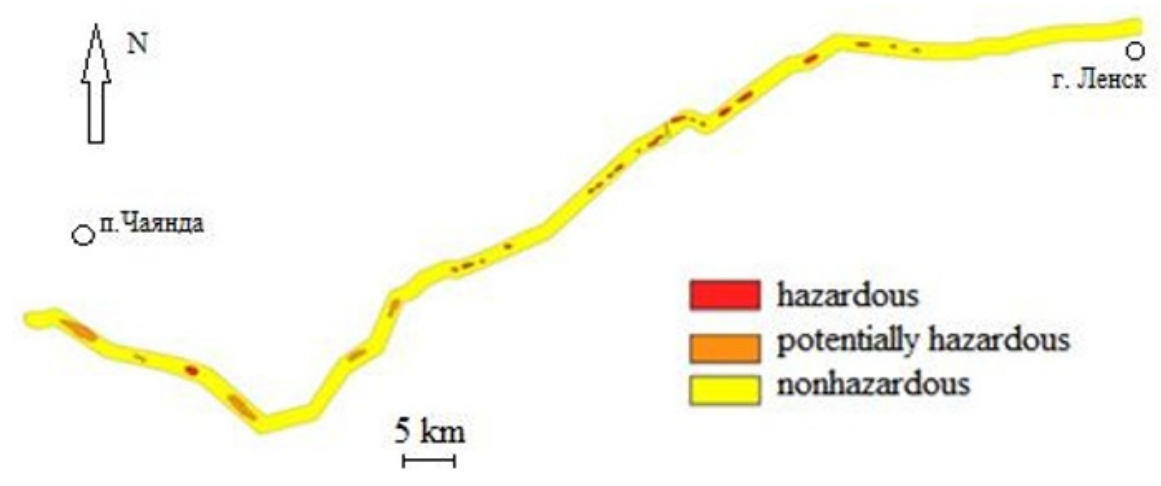

Fig. 3. Zoning according to karst hazard ranking.

\section{Conclusion}

The paper presents schemes of zoning according to the degree of danger of subsidence of the earth's surface in the zone of influence of the main gas pipeline in South Yakutia. The analysis of literature sources, data of engineering-geological conditions of the area of construction of the gas pipeline allowed to reveal conditions and factors of subsidence of a surface as a result of karst.

The spatial analysis of indicators of natural conditions made it possible to determine the areas of development of processes in the strip of the main gas pipeline with different probability.

The calculation of the diameter of the karst failure in hazardous areas to determine the need for compensation measures. The results can be used to justify the use of engineering protection in the project documentation and to optimize geotechnical monitoring activities.

The research is carried out at Tomsk Polytechnic University within the framework of Tomsk Polytechnic University Competitiveness Enhancement Program grant.

\section{References}

1. N.A. Gvozdetsky Karst (Moscow: Mysl), 214 (1981)

2. N.A. Gvozdetsky. Karst landscapes (Moscow: Moscow University Publishing House), 112 (1988)

3. G.A. Maksimovich. The basics of karst studies (Perm: Perm University Publishing House) 1, 443 (1963)

4. L.A. Strokova, A.V. Ermolaeva, V.V. Golubeva. IOP Conference Series: Earth and Environmental Science, 43 (2016)

5. L.A. Strokova, A.V. Ermolaeva. Bull. of the Tom. Polyt. Univ., 326 (4), 41-55 (2015)

6. L.A. Strokova, A.V. Ermolaeva. Bull. of the Tom. Polyt. Univ. Geo As. Eng., 327 (10) 59-68 (2016)

7. Z.A. Makeev. Principles of geoengineering zoning Karst Study, 4, 43 (1948)

8. V.V. Tolmachev, G.M. Troitskii, V.P. Khomenko / Ed. Sorochan E.A. Engineeringgeological exploration of karsting territory, 176 (1986) 